\title{
MEMORANDUM. \\ A BODKIN FOR STRABISMUS OPERATIONS
}

BY

W. O. LODGE

HALIFAX

A miniatuRE self-retaining strabismus hook was designed by me some years ago.

Messrs. Weiss now make to my pattern a bodkin from thicker stainless steel wire, grinding the handle and the hook with its terminal eye to the original gauge, but forging the middle third into a grooved director, curved on the flat.

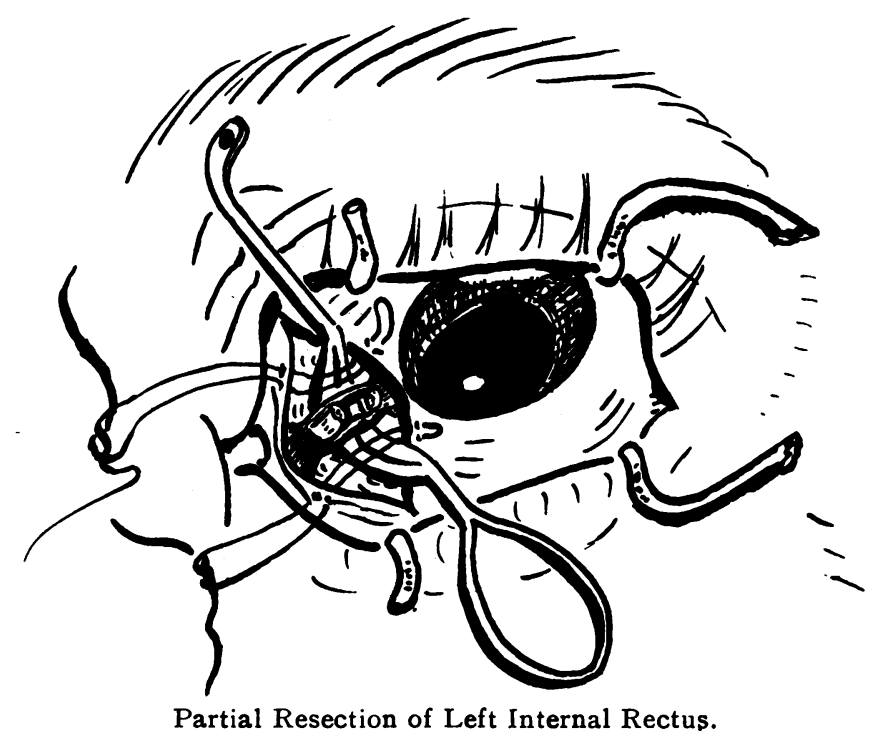

The bodkin renders an extra ocular muscle accessible and puts it at rest, as shown in the accompanying diagram.

The dimensions of the instrument are as follows :

$\begin{array}{lccccc}\text { Overall length } & \ldots & \ldots & \ldots & \ldots & 69 \mathrm{~mm} . \\ \text { Hook } \ldots & \ldots & \ldots & \ldots & \ldots & 7 \mathrm{~mm} . \times 1 \mathrm{~mm} . \\ \text { Shaft of Hook } & \ldots & \ldots & \ldots & \ldots & 18 \mathrm{~mm} . \\ \text { Chord of flattened portion } & \ldots & \ldots & 20 \mathrm{~mm} . \\ \text { Width of flattened portion } & \ldots & \ldots & 5 \mathrm{~mm} . \\ \text { Radius of curvature of flattened portion } & 10 \mathrm{~mm} . \\ \text { Shaft of handle } & \ldots & \ldots & \ldots & \ldots & 7 \mathrm{~mm} . \\ \text { Looped handle } & \ldots & \ldots & \ldots & \ldots & 20 \mathrm{~mm} . \times 9 \mathrm{~mm} . \times 1 \mathrm{~mm} .\end{array}$ 